\title{
CORPORATE RESPONSIBILITY FOR HUMAN RIGHTS VIOLATIONS
}

\author{
BENCE UDVARHELYI
}

\begin{abstract}
The international legal liability of companies for human rights violations is a very current issue, since nowadays multinational and transnational corporations more and more frequently violate human rights. However, the establishment of the direct international legal liability of business actors for human rights violations is a long and difficult process. The present study seeks to analyse the efforts of the United Nations in this regard.
\end{abstract}

Keywords: human rights, corporate responsibility, UN, soft law documents, international liability

\section{INTRODUCTORY REMARKS}

A superficial observer may think that the world of business does not or only in the rarest cases connect to human rights. The reason for this is that human rights primarily aim to protect persons against arbitrary legislation or state measures, therefore according to the traditional view - the two areas can only overlap if the state restricts or violates fundamental human rights that, by the virtue of their nature, affect legal persons as well. ${ }^{1}$ Such fundamental rights can be e.g. the right to property or the protection of good will and reputation.

However, we should not forget the other pole of the relationship between business and human rights, since business actors can not only be the victims but also - and in the recent years more and more frequently ${ }^{2}$ - perpetrators of human rights violations.

Multinational enterprises can commit human rights violations both directly and indirectly. In the first case, the transnational company directly violates certain human rights with its actions or omissions. A direct violation of fundamental rights can be, for example, if a company uses child or forced labour, does not provide the necessary safety and health guarantees, creates inhumane working conditions, pollutes the environment or discriminates in the workplace. In contrast, in case of an indirect violation the enterprise is merely a participant or beneficiary of human rights violations caused by the state, for example during an armed conflict or by the service of a totalitarian regime. ${ }^{3}$ The indirect violations have become particularly widespread recently, since transnational enterprises are pursuing business activity more and more frequently in a socially and politically unstable environment as a result of the

Assistant professor, University of Miskolc, Faculty of Law, Institute of Criminal Sciences.

1 See: SÁNDOR, Lénárd: Az emberi jogok és az üzlet világának nemzetközi jogi kérdései. Jogtudományi Közlöny, 2016/4, p. 214.

2 See: LeISINGER, Klaus M.: Business and human rights. In: The Future of Sustainability (ed.: KEINER, Marco). Springer Verlag, Dordrecht, 2006, 117-118.

3 CHRONOWSKI, Nóra: Üzlet és emberi jogok - nemzetközi törekvések és alkotmányjogi korlátok. Jura, 2013/2, 8. 
increasing liberalization of international trade and foreign capital investment and the growth of cross-border business activity. The rise of the number of fundamental rights violations committed by legal persons is also facilitated by the fact that transnational enterprises are commercially and economically homogeneous, but they have separate legal entities in each of the countries in which they operate. This regulatory fragmentation can also contribute to human rights violations by legal entities, especially in states - particularly in Africa, Asia and Latin America ${ }^{4}$ - where the government and administration is weaker. ${ }^{5}$

The efforts to promote and enforce human rights in the business world (Business and Human Rights - BHR) have been present on the stage of international law since the 2000s, but their roots can already be found in the concept of corporate social responsibility (CSR). This latter notion has emerged at the turn of the 1960s and 1970s and can be regarded as a form of corporate self-regulation integrated into the business model through which the company ensures, guarantees and monitors the compliance with legal, ethical and international requirements. However, the idea of the enforcement of human rights in business activities goes beyond the concept of the self-regulative corporate social responsibility, since it envisages the extension of human rights obligations to multinational, transnational and other companies, and therefore it foresees the gradual creation of enforceable obligations, and the establishment of direct international legal liability of companies for human rights violations caused by them or by their interference. ${ }^{6}$

However, the achievement of this goal is a long, cumbersome and slow process. In case of a violation of fundamental rights by business actors, the currently effective international human rights conventions provide primarily for the international law liability of the state in which the business is conducted, and not the company itself. Regional and universal human rights conventions require the states to ensure that all persons under their jurisdiction enjoy the rights guaranteed to them. ${ }^{7}$ Consequently,

4 See in details: RugGIE, John: Just Business. Multinational Corporations and Human Rights. W.W. Norton and Company, New York-London, 2013, 47-56.

5 SÁNDOR: 2016, op. cit. 215-217. See also: SÁNDOR Lénárd: Vállalati társadalmi felelősségvállalás a nemzetközi jogban. Jogtudományi Közlöny, 2017/4, 174-175.

6 CHRONOWSKI: op. cit. 7, 14.

7 See for example: Article 2(1) of the International Covenant on Civil and Political Rights: "Each State Party to the present Covenant undertakes to respect and to ensure to all individuals within its territory and subject to its jurisdiction the rights recognized in the present Covenant, without distinction of any kind, such as race, colour, sex, language, religion, political or other opinion, national or social origin, property, birth or other status. "; Articles 2(1) and 3 of the International Covenant on Economic, Social and Cultural Rights "Each State Party to the present Covenant undertakes to take steps, individually and through international assistance and co-operation, especially economic and technical, to the maximum of its available resources, with a view to achieving progressively the full realization of the rights recognized in the present Covenant by all appropriate means, including particularly the adoption of legislative measures". "The States Parties to the present Covenant undertake to ensure the equal right of men and women 
human rights violations committed by companies also give rise to the liability of the state on the ground that it has violated its obligation to provide the effective exercise of the rights under the relevant human rights convention. ${ }^{8}$ It can therefore be seen that international law does not recognize the international legal personality and international legal responsibility of companies; human rights conventions only impose indirect human rights obligations on business actors.

However, the mere prescription of the state liability does not always provide effective protection against human rights violations committed by businesses. As a result of this, there is a growing need to establish direct international legal responsibility for business actors. These efforts have emerged in a number of international organisations, e.g. within the framework of the United Nations, the European Union $^{9}$, the Council of Europe ${ }^{10}$, the Organisation for Economic Co-operation and Development $^{11}$ and the International Labour Organisation ${ }^{12}$. In the context of this paper, we would like to focus only on the activity of the United Nations in this field.

to the enjoyment of all economic, social and cultural rights set forth in the present Covenant." Article 1 of the European Convention on Human Rights: "The High Contracting Parties shall secure to everyone within their jurisdiction the rights and freedoms defined in Section I of this Convention.’'. See also: KovÁcs Péter: Nemzetközi közjog. Osiris Kiadó, Budapest, 2011, pp. 318-319.

8 SÁNDOR: 2016, op. cit. 217. See also: CHRONOWSKI: op. cit. 13.

9 Within the framework of the European Union, the European Commission and the European Parliament have adopted non-binding instruments on corporate social responsibility and liability for human rights violations. See for example: Green Paper of the European Commission - Promoting a European framework for corporate social responsibility $[\operatorname{COM}(2001) 366,18.7 .2001]$; Communication from the Commission to the European Parliament, the Council, the European Economic and Social Committee and the Committee of the Regions: A renewed EU strategy 2011-14 for Corporate Social Responsibility [COM(2011) 681, 25. 10. 2011]; Resolution of the European Parliament of 6 February 2013 on corporate social responsibility: accountable, transparent and responsible business behaviour and sustainable growth [2012/2098(INI), P7_TA(2013) 49, 6. 2. 2013]; Resolution of the European Parliament of 6 February 2013 on Corporate Social Responsibility: promoting society's interests and a route to sustainable and inclusive recovery [2012/2097(INI), P7_TA(2013) 50, 6. 2. 2016]; Resolution of the European Parliament of 25 October 2016 on corporate liability for serious human rights abuses in third countries [2015/2315(INI), P8_TA(2016) 405, 25. 10. 2016].

10 The Committee of Ministers of the Council of Europe adopted a recommendation on the relationship between human rights and business actors on the 2nd March 2016. See: Recommendation CM/Rec(2016)3 of the Committee of Ministers to Member States on Human Rights and Business.

11 The OECD Declaration on International Investment and Multinational Enterprises has been adopted in 1976 and has been comprehensively reviewed in 1979, 1984, 1991, 2000 and 2011. See in details: SÁNDOR: 2017, op. cit. 175-176.

12 Within the framework of the ILO, the states have adopted a Tripartite Declaration of Principles concerning Multinational Enterprises and Social Policy in 1977. 


\section{THE ACTIVITY OF THE UNITED NATIONS IN CONNECTION WITH THE CORPO- RATE RESPONSIBILITY FOR HUMAN RIGHTS VIOLATION}

\subsection{The first results of the United Nations}

The idea of developing normative international rules defining the legal framework for the activities of multinational and transnational enterprises has almost been simultaneous to the strengthening of the international human rights protection. The first general and universal human rights conventions within the framework of the United Nations - the International Covenant on Civil and Political Rights and the International Covenant on Economic, Social and Cultural Rights - were opened for signature to the member states of the UN in 1966, while the efforts relating the establishment of the human rights responsibility of businesses go back to the 1970s. ${ }^{13}$

In the early 1970s, the Economic and Social Council of the United Nations initiated the UN Secretary-General to establish a committee to examine the impact of transnational corporations on the development and on international relations. ${ }^{14}$ On the basis of this, the Economic and Social Council ${ }^{15}$ set up the United Nations Commission on Transnational Corporation (UNCTC) in 1974. The UNCTC consists of experts from a total of 48 states, selected by the Economic and Social Council based on equitable geographical distribution, for a period of three years. The Commission acts as a forum within the United Nations System for consideration of issues relating to international investment and transnational corporations; it promotes exchange of views among governments, inter-governmental organisations, trade unions, business, consumer and other relevant groups; it assists governments in attracting investment and in dealing with transnational corporations; it contributes in the further understanding of the nature of transnational corporations; and it strengthens the capacity of developing countries in their dealings with them through an integrated approach including research, information and technical assistance. ${ }^{16}$

The UNCTC set out the aim to develop a binding code of conduct for transnational corporations in order to maintain and protect international human rights standards in business. The document of the UNCTC would have regulated the rights and obligations of transnational corporations and their receiving states, including the treatment of transnational corporations, the intergovernmental cooperation and the implementation of codes of conduct of the business actors. The final draft was finished in $1990^{17}$, however, it did not win the support of the states. ${ }^{18}$

3 SÁNDOR: 2016, op. cit. 218.

14 SÁNDOR: 2016, op. cit. 218.

15 Resolution 1913 (LVII) of the Economic and Social Council (ECOSOC) of 5th December 1974 on the impact of transnational corporations on the development process and on international relations.

16 https://uia.org/s/or/en/1100059616 (25. 11. 2020).

17 Draft United Nations Code of Conduct on Transnational Corporations.

18 SÁNDOR: 2016, op. cit. 218-219. See in details: SAUVANT, Karl P.: The Negotiations of the United Nations Code of Conduct on Transnational Corporations. The Journal of World Investment and Trade, Vol. 16, 2005, 11-87. 


\subsection{The UN Global Contract}

The next step in the process of establishing corporate responsibility for human right violations was the United Nations Global Compact. The creation of the Global Compact was proposed by Secretary-General Kofi Annan at the World Economic Forum in Davos, Switzerland, on the 31st March 1999. The document, which was adopted in 2000, can be regarded as a voluntary framework agreement for business life, which aimed at creating a sustainable, stable, inclusive global economy, protecting human rights, the environment and the labour standards within the own sphere of operation of the company. ${ }^{19}$

The UN Global Contract sets out ten principles in the areas of human rights ${ }^{20}$, environment ${ }^{21}$, labour law ${ }^{22}$ and the fight against corruption ${ }^{23}$, which business actors must respect and promote. The Global Compact specifically emphasizes that companies are prohibited to contribute to, aid in or benefit from human rights violations. However, the Global Contract is a soft law document, i.e. it is not legally binding, since it lacks standards for monitoring and evaluating corporate conduct and it does not prescribe legal consequences in case of the violation of the principles. In the absence of an effective control and enforcement mechanism, the compliance with the principles depends solely on the willingness and voluntary commitment of the legal persons. ${ }^{24}$ However, success of the Global Contract is well illustrated by the fact that more than 11,000 companies have adopted its standards in their own operations so far. ${ }^{25}$

\subsection{The Norms on the Responsibilities of Transnational Corporations and Other Business Enterprises with Regard to Human Rights}

In 2003, the UN Human Rights Council published the Norms on the Responsibility of Transnational Corporations and Other Business Enterprises with Regard to Human Rights.

19 CHRONOWSKI: op. cit. pp. 8, 15.

20 Principle 1: Businesses should support and respect the protection of internationally proclaimed human rights; and Principle 2: make sure that they are not complicit in human rights abuses.

21 Principle 3: Businesses should uphold the freedom of association and the effective recognition of the right to collective bargaining; Principle 4: the elimination of all forms of forced and compulsory labour; Principle 5: the effective abolition of child labour; and Principle 6: the elimination of discrimination in respect of employment and occupation.

22 Principle 7: Businesses should support a precautionary approach to environmental challenges; Principle 8: undertake initiatives to promote greater environmental responsibility; and Principle 9: encourage the development and diffusion of environmentally friendly technologies.

23 Principle 10: Businesses should work against corruption in all its forms, including extortion and bribery.

24 ChronOwSKI: op. cit. 8; SÁNDOR: 2016, op. cit. 221; SÁNDOR: 2017, op. cit. 178.

25 https://www.unglobalcompact.org (25. 11. 2020). 
According to the Norm, the states have the primary responsibility to promote, secure the fulfilment of, respect, ensure respect of and protect human rights recognized in international as well as national law. Within the framework of this obligation, the states are also required to ensure that transnational corporations and other business enterprises respect human rights. The Norms also prescribe to the transnational corporations and other business enterprises to promote, respect, and protect human rights within their respective spheres of activity and influence, including the rights and interests of indigenous peoples and other vulnerable groups. ${ }^{26}$ Among the human rights to be guaranteed by business actors, the document explicitly mentions the right to equal opportunity and treatment; the prohibition of discrimination based on race, colour, sex, language, religion, political opinion, national or social origin, social status, indigenous status, disability, age or other status; the prohibition of forced or compulsory labour; the rights of children to be protected from economic exploitation; the right to a safe and healthy working environment; the right of workers to proper remuneration that ensures an adequate standard of living for them and their families; the freedom of association; and the right to collective bargaining. ${ }^{27}$ The corporations and business enterprises shall not engage in nor benefit from war crimes, crimes against humanity, genocide, torture and other international criminal offences. ${ }^{28}$ Transnational corporations shall recognize and respect the applicable norms of international law; national laws, regulations, and administrative practices; economic, social and cultural rights as well as civil and political rights; the rule of law, the public interest, development objectives, social, economic and cultural policies including transparency, accountability and prohibition of corruption. ${ }^{29}$ Furthermore, the business actors are also required to ensure the continuous compliance with consumer protection and environmental principles and rules. ${ }^{30}$

The Norms prescribe that the business actors shall adopt, disseminate and implement internal rules of operation in compliance with the Norms. They are required to periodically report on and take other measures fully to implement the Norms. The application of the Norms shall be continuously monitored and verified transparently and independently. States should establish and reinforce the necessary legal and administrative framework for ensuring that the Norms and other relevant national and international laws are implemented by transnational corporations and other business enterprises. Furthermore, transnational business enterprises shall provide prompt, effective and adequate reparation to those persons, entities and communities that have been adversely affected by failures to comply with these Norms through, inter alia, reparations, restitution, compensation and rehabilitation for any damage done or property taken. ${ }^{31}$

26 Point 1 of the Norms.

27 Points 2 and 5-9 of the Norms.

28 Points 3-4 of the Norms.

29 Points $10-12$ of the Norms.

30 Points 13-14 of the Norms.

31 Points $15-18$ of the Norms. 
As it can be seen, a significant innovation of the Norms is that on the one hand it provides for a system of continuous, periodic, independent and public monitoring system, allowing complaints to be lodged, and on the other hand it provides for legal consequences, including compensation for damage caused. Because of these rules it seems that the authors of the document sought to go beyond the soft law nature of the rules. However, the business world and some states have opposed the Norms because of the endeavour of the introduction of direct international legal obligations on companies and of the prescription of a mandatory control mechanism. Therefore, the UN Human Rights Council has pronounced in a resolution that the Norms are not binding. ${ }^{32}$

\subsection{UN Guiding Principles on Business and Human Rights}

In 2005, the Secretary-General of the United Nations appointed John Gerard Ruggie as Special Representative for Business and Human Rights, with the aim of assessing the issues affecting the fundamental responsibilities of business actors. The task was not to draft a new international treaty, but to comprehensively analyse and systematize the liability of companies for human rights violations through the review of the rules of international law. As a result of the work of the Special Representative, the United Nations "Protect, Respect and Remedy" Framework for Business and Human Rights ${ }^{33}$ was presented to the UN Human Rights Council in 2008. On the 16th June 2011, the Human Rights Council adopted the UN Guiding Principles on Business and Human Rights (UNGP) which serves as the implementation of the "Protect, Respect and Remedy" Framework Program. The UNGP was the first document of the initiatives on the relationship between human rights and the business world which gained the support of the UN Human Rights Council, through which it became an international standard for business conduct. The UNGP was the first international document which established global standards for the protection against the harmful effects of business on human rights. ${ }^{34}$

The UNGP distinguishes between three main pillars of corporate human rights responsibility. The first pillar is the obligation of the states to respect, protect and fulfil human rights and fundamental freedoms within their territory and/or jurisdiction. In this context, the states are required to protect against human rights abuse by third parties, including business enterprises and to take appropriate steps to prevent, investigate, punish and redress such abuse through effective policies, legislation, regulations and adjudication. ${ }^{35}$ States should set out clearly the expectation that all business enterprises domiciled in their territory and/or jurisdiction respect human rights throughout their operations. ${ }^{36}$ The responsibility of the state is increased in

32 SÁNDOR: 2016, op. cit. 219-220; SÁNDOR: 2017, op. cit. 176. See also: CHRONOWSKI: op. cit. 9 .

33 See in details: RUGGIE: op. cit. 189-212.

34 CHRONOWSKI: op. cit. 9; SÁNDOR: 2016, op. cit. 221.

35 Point 1 of the UNGP.

36 Point 2 of the UNGP. 
cases where the state is involved in the business actor, e.g. in case of business enterprises that are owned or controlled by the state, or that receive substantial support and services from state agencies; and where the business actor operates in a conflictaffected area. ${ }^{37}$ Furthermore, the states are obliged to ensure that governmental departments, agencies and other state-based institutions are aware of and observe the state's human rights obligations. ${ }^{38}$

The second pillar of the UNGP focuses on business enterprises and requires legal entities - regardless of their size, sector, operational context, ownership and structure - to respect human rights during their operation. In this context, the business enterprises should on the one hand avoid causing or contributing human rights infringements, and on the other hand seek to prevent or mitigate adverse human rights impacts that are directly linked to their operations, products or services by their business relationships. ${ }^{39}$ In order to identify, prevent, mitigate human rights abuses and infringements, the UNGP prescribes a human rights due diligence obligation to business actors. Within the framework of the due diligence obligation, business enterprises are required to assess the actual and potential human rights impacts, that the business enterprise may cause or contribute to through its own activities, or which may be directly linked to its operations, products or services by its business relationships; to integrate and act upon the findings, to track responses, and to communicate how impacts are addressed. The due diligence obligation should be ongoing, and the finding has to be amended and updated if necessary, since human rights risks may change over time as the operating context of the business enterprise evolve. ${ }^{40}$ In order to prevent and mitigate adverse human rights impacts, business enterprises should integrate the findings from their impact assessments across relevant internal functions and processes, and take appropriate action. ${ }^{41}$ If business enterprises identify that they have caused or contributed to adverse impacts, they should provide for or cooperate in their remediation through legitimate processes. ${ }^{42}$

Finally, the third pillar of the UNGP consists of the legal remedies. As part of the duty of the states to protect against business-related human rights abuses, they are required to take appropriate steps to ensure, through judicial, administrative, legislative or other appropriate means, that the affected persons have access to effective remedy when such abuses occur within their territory and/or jurisdiction. ${ }^{43}$ The UNGP distinguished between state-based and non-state-based judicial and non-judicial grievance mechanisms. ${ }^{44}$ In order to ensure their effectiveness, the grievance

\footnotetext{
Points 4-7 of the UNGP.

Points $8-10$ of the UNGP.

Points 11 and 13-14 of the UNGP.

Point 17 of the UNGP.

Point 19 of the UNGP.

Point 22 of the UNGP.

Point 25 of the UNGP.

44 Points 27-30 of the UNGP.
} 
measures has to be legitimate, accessible, predictable, equitable, transparent and compatible with the internationally recognized human rights. ${ }^{45}$

In a formal sense, the UNGP cannot be considered a compulsory source of law, however, it can serve as a guideline for assessing the activities of companies, because it summarizes the relevant national and international legal standards. The document was adopted as a joint compromise between the various stakeholders, therefore it was welcomed both by the states, the business actors and the civil society organizations. The disadvantages of the UNGP are that it only sets out minimum standards due to its consensual nature, and that - although it prescribes direct standards for businesses - it does not provide for legal consequences or sanctions for companies that violate the principles. ${ }^{46}$

\subsection{The UN Legally Binding Instrument}

In 2014, the UN Human Rights Council set up a Working Group to develop an international legally binding instrument governing the activities of transnational and other businesses that could contribute to effective action against human rights violations committed by them. ${ }^{47}$ The working group published its first draft in $2018^{48}$, which was revised in $2019^{49}$ and $2020 .^{50}$

The purpose of the Draft Convention is to clarify and facilitate the effective implementation of the obligation of states to respect, protect and promote human rights in the context of business activities, as well as the responsibilities of business enterprises in this regard; to prevent the occurrence of human rights abuses ${ }^{51}$ in the context of business activities; to ensure access to justice and effective remedy for victims ${ }^{52}$

45 Point 31 of the UNGP.

46 SÁNDOR: 2016, op. cit. 222-223.

47 Resolution 26/9 of 14 July 2014 adopted by the Human Rights Council on the elaboration of an international legally binding instrument on transnational corporations and other business enterprises with respect to human rights.

48 Legally Binding Instrument to Regulate, in International Human Rights Law, the Activities of Transnational Corporations and other Business Enterprises, Zero Draft, 16. 7. 2018.

49 Legally Binding Instrument to Regulate, in International Human Rights Law, the Activities of Transnational Corporations and other Business Enterprises, Revised Draft, 16. 7. 2019.

50 Legally Binding Instrument to Regulate, in International Human Rights Law, the Activities of Transnational Corporations and other Business Enterprises, Second Revised Draft, 6. 8. 2020.

51 Under Article 1(2) of the Draft Convention, human rightsabuse shallmean any harmcommittedby abusinessenterprise, through acts or omissions in the context of business activities, against any person or group of persons, that impedes the full enjoyment of internationally recognized human rights and fundamental freedoms, including regarding environmental rights.

52 Under Article 1(2) of the Draft Convention, victim can be any persons or group of persons who individually or collectively have suffered harm, including physical or mental injury, emotional suffering, or economic loss, or substantial impairment of their human rights, through acts or omissions in the context of business activities, that constitute human rights abuse. The term victim shall also include the immediate family members or dependents 
of human rights abuses in the context of such business activities; and to facilitate and strengthen mutual legal assistance and international cooperation to prevent human rights abuses in the context of business activities and provide access to justice and effective remedy to victims of such abuses. ${ }^{53}$ The scope of the Draft Convention encompasses all business enterprises, including but not limited to transnational corporations and other business enterprises that undertake business activities of a transnational character. ${ }^{54}$

The Draft Convention firstly deals with the position of the victims of human rights abuses in the context of business activities, who shall enjoy all internationally recognized human rights and fundamental freedoms, in particular the right to human dignity, life, personal integrity, freedom of opinion and expression, peaceful assembly and association, and free movement; the right to fair, adequate, effective, prompt and non-discriminatory access to justice and effective remedy; the right to submit claims; and the access to information and legal aid relevant to pursue effective remedy. However, the Draft Convention only contains minimum rules in connection with the rights of victims, which does not hinder the states to provide for a higher level of recognition and protection of any human rights of victims or other individuals under international law or national law. ${ }^{55}$

The obligations of states are distinguished into three main categories according to the Draft Convention: the obligation to protect, the obligation to prevent and the obligation to determine liability.

The states shall protect victims, their representatives, families and witnesses from any unlawful interference with their human rights and fundamental freedoms - including prior, during and after they have instituted any proceedings to seek access to effective remedy - and shall investigate all human rights abuses effectively, promptly, thoroughly and impartially. The states are required to enable the victims to access to adequate, timely and effective remedies and to provide adequate and effective legal assistance throughout the legal process, including by making information available to victims of their rights and the status of their claims, guaranteeing the rights of victims to be heard in all stages of proceedings, avoiding unnecessary costs and by providing assistance to initiate proceedings in the courts of another states. ${ }^{56}$

Within the framework of the obligation of prevention, the Draft Convention prescribes to the states to effectively regulate the activities of all business enterprises domiciled within their territory or jurisdiction, including those of a transnational character, and to take all necessary legal and policy measures to ensure that business enterprises

of the direct victim, and persons who have suffered harm in intervening to assist victims in distress or to prevent victimization. A person shall be considered a victim regardless of whether the perpetrator of the human rights abuse is identified, apprehended, prosecuted, or convicted.

53 Article 2 of the Draft Convention.

54 Article 3 of the Draft Convention.

55 Article 4 of the Draft Convention.

56 Articles 5 and 7 of the Draft Convention. 
respect all internationally recognized human rights and prevent and mitigate human rights abuses throughout their operations. In connection with this, the Draft Convention obliges the states to require business enterprises to undertake human rights due diligence in order to identify and assess any actual or potential human rights abuses that may arise from their own business activities, or from their business relationships; to take appropriate measures to prevent and mitigate effectively the identified actual or potential human rights abuses; and to monitor the effectiveness of their measures. ${ }^{57}$

States shall ensure that their domestic law provides for a comprehensive and adequate system of legal liability of legal and natural persons conducting business activities for human rights abuses. If legal or natural persons conducting business activities have caused or contributed to criminal offences or other regulatory breaches that amount or lead to human rights abuses, the states shall provide for effective, proportionate, and dissuasive criminal and/or administrative sanctions. Victims of human rights abuses must be provided for adequate, prompt, effective, and gender responsive reparations. ${ }^{58}$

Since human rights abuses and violations committed by transnational corporations often involve more than one state, the Draft Convention regulates the issue of choice of jurisdiction and applicable law. ${ }^{59}$ Furthermore, the states shall make available to one another the widest measure of mutual legal assistance and international judicial cooperation in initiating and carrying out effective, prompt, thorough and impartial investigations, prosecutions, judicial and other criminal, civil or administrative proceedings, including access to information and supply of all evidence at their disposal that is relevant for the proceedings. Mutual legal assistance includes e.g. the taking of evidence or statements from persons, the execution of searches and seizures, the examination of objects and sites, the provision of originals or certified copies of relevant documents and records, the identification, tracing and freeze of proceeds and assets of crime, and any other type of assistance. The international cooperation between states covers the effective financial and technical assistance and capacity building; the share of experiences, good practices, challenges, information and training programs; and the raise of awareness about the rights and obligations arising out of the Draft Convention. ${ }^{60}$

Among the procedural provisions of the Draft Convention, it should be highlighted that a Committee of 18 experts would be set up. The members of Committee shall be elected by the State Parties for a term of 4 years and can be re-elected for another term. The State Parties are required to submit a report every four years on the measures they have taken in order to implement the provisions of the Draft Convention. The Committee can also make general comments and normative recommendations on the understanding and implementation of the Draft Convention

57 Article 6 of the Draft Convention.

58 Article 8 of the Draft Convention.

59 Articles 9 and 11 of the Draft Convention.

60 Articles 12-13 of the Draft Convention. 
and is obliged to submit an annual report on its activities to the State Parties and to the General Assembly of the United Nations. ${ }^{61}$

\section{Closing Remarks}

As it could be seen, the issue of the liability of multinational and transnational corporations for human rights violations has been on the agenda of international organizations, especially of the United Nations, since the 1970s. Within the framework of the UN, several documents have been adopted that prescribe various legal and ethical guidelines for business actors. However, all the documents adopted are soft law in nature; they are not legally binding. This fact clearly shows that it is very difficult to define normative obligations in this area due to the resistance of some states and representatives of the business world.

The Draft Convention, which was issued within the framework of the United Nations in 2018 and was subsequently revised twice, can be regarded as the first international legal document that would contain binding rules on the human rights liability of transnational and other business enterprises as opposed to the soft law rules of previous international legal acts. Therefore, it is no exaggeration to state that the adoption of the Draft Convention, which is still under negotiation, would be a significant milestone in the regulation of corporate responsibility for human rights violations.

\section{LIST OF LITERATURE}

[1] ChronOWSKI Nóra: Üzlet és emberi jogok - nemzetközi törekvések és alkotmányjogi korlátok. Jura, 2013/2.

[2] KovÁCs Péter: Nemzetközi közjog. Osiris Kiadó, Budapest, 2011.

[3] LEISINGER, Klaus M.: Business and human rights, in: The Future of Sustainability (ed.: Keiner, Marco). Springer Verlag, Dordrecht, 2006. https://doi.org/10.1007/1-4020-4908-0_6

[4] RUGGIE, John: Just Business. Multinational Corporations and Human Rights. W.W. Norton and Company, New York-London, 2013.

[5] RUGGIE, John: Protect, Respect and Remedy. A Framework for Business and Human Rights. Innovations Technology Governance Globalization, Vol. 3/2, 2008, https://doi.org/10.1162/itgg.2008.3.2.189.

[6] SÁNDOR Lénárd: Az emberi jogok és az üzlet világának nemzetközi jogi kérdései. Jogtudományi Közlöny, 2016/4.

61 Article 15 of the Draft Convention. 
[7] SÁNDOR Lénárd: Vállalati társadalmi felelősségvállalás a nemzetközi jogban. Jogtudományi Közlöny, 2017/4.

[8] SaUVAnT, Karl P.: The Negotiations of the United Nations Code of Conduct on Transnational Corporations. The Journal of World Investment and Trade, Vol. 16, 2005. 